Géographie physique et Quaternaire

\title{
On Sampling and Sorting of Pebbles and Cobbles on Shores, a Reply to Matti Seppälä's Comment on "Shape Development of Trondhjemite Pebbles and Cobbles on Shores in the Southwestern Finnish Archipelago", by Mauri Pyökäri (1980)
}

\section{Mauri Pyökäri}

Volume 36, numéro 3, 1982

URI : https://id.erudit.org/iderudit/032487ar

DOI : https://doi.org/10.7202/032487ar

Aller au sommaire du numéro

Éditeur(s)

Les Presses de l'Université de Montréal

ISSN

0705-7199 (imprimé)

1492-143X (numérique)

Découvrir la revue

Citer ce document

Pyökäri, M. (1982). On Sampling and Sorting of Pebbles and Cobbles on Shores, a Reply to Matti Seppälä's Comment on "Shape Development of Trondhjemite Pebbles and Cobbles on Shores in the Southwestern Finnish Archipelago", by Mauri Pyökäri (1980). Géographie physique et Quaternaire, 36(3), 332-334. https://doi.org/10.7202/032487ar 


\section{ON SAMPLING AND SORTING OF PEBBLES AND COBBLES ON SHORES, A REPLY TO MATTI SEPPÄLÄ'S COMMENT ON "SHAPE DEVELOPMENT OF TRONDHJEMITE PEBBLES AND COBBLES ON SHORES IN THE SOUTHWESTERN FINNISH ARCHIPELAGO", BY MAURI PYÖKÄRI (1980)}

Mauri PYÖKÄRI, Department of Geography, University of Turku, SF-20500 Turku 50, Finland.

Along with several minor comments Dr. Seppälä makes three major points about my study on the shape development of trondhjemite clasts (PYÖKÄRI, 1980) : 1) the sampling technique has homogenized the clast material, and therefore the values obtained represent artificial populations; 2) till samples and moraine-shore samples cannot be compared with one another; and 3) longshore drift has split clast populations into sub- 
populations of varying sphericity on different stretches of the shore. I would like first to address myself to these major points and then turn to the minor comments.

Dr. Seppälä claims that the sampling method used in my study is not correct because the complete size distributions in esker, till and shore materials are not known, because the sampling technique has homogenized the material, and therefore the measured values represent artificial populations. According to $\mathrm{Dr}$. Seppälä, the size classes (sub-size groups in his text) of trondhjemite clasts ought to have been determined by bulk sampling on the basis of the total distribution of the clasts in the area, if I have understood him correctly. If he means that I should have formed my own size classes for the study area, then it would not have been possible to use the common phi-unit classification and thus the results of my study would not have been comparable with other studies. If, however, Dr. Seppälä means that the weighted classes using the phiunit classification (16-32 mm, 32-64 mm, 64-128 mm, $128-256 \mathrm{~mm}$ ) should have been formed by bulk sampling and should have been used in the calculation, then what would have been the advantage of this sampling technique? Much more work and calculating; for example, 300-400 clasts ought to have been included in the bulk sampling to ensure a sufficient by large number of clasts of the largest size class. It would perhaps have explained more about what happens to till and esker materials in the area, but that was not the purpose of this study.

The aim of this study is only to show, using four size classes, how the shape of trondhjemite clasts of 16-256 $\mathrm{mm}$ changes when clasts taken from till and esker materials, are transported to the shore, and not what happens to these materials on the shore as a whole. The sampling method, classification, and indices used in this study have been widely used by geologists and physical geographers (e.g. DOBKINS and FOLK, 1970; KAITANEN and STRÖM, 1978) and they have been considered to be valid for the last 15 years. As I have studied only the shape changes in trondhjemite clasts distributed in four size classes on the shore, it is quite valid to compare the means of the classes and the means of all sizes in each category. The means of all sizes do not represent the true nature of esker, till, or beach materials, only the means of trondhjemite clasts of $16-256 \mathrm{~mm}$ in these materials. There are also clasts that come from all layers of till and esker, because they were taken randomly. Numerous random samples (1200 clasts) were taken from moraine shores to ensure that clasts from every till layer were included in the samples.

As to Dr. Seppälä's second comment, that moraineshore clasts cannot be compared with till clasts because most of the moraine shores are located at about $25 \mathrm{~km}$ from the till sampling sites, it must be remembered that the topic studied here is only that of shape changes in trondhjemite clasts, not till material as a whole. Because trondhjemite is a common rock type in the study area as well as in the area from which the continental ice sheet came (HIETANEN, 1947; HÄRME, 1960), trondhjemite clasts, both at till sampling sites and at sampling sites on moraine shores, originate from various trondhjemite bedrock sites. Consequently, the distribution of transportation distances (i.e. degrees of glacial wearing) of trondhjemite clasts at each sampling site is much the same. Therefore clasts are statistically similar at till sampling sites and at moraineshore sampling sites. In the samples taken from moraine shores there are trondhjemite clasts from every till layer, transported on varying distances because the number of the clasts is very large. For these reasons, mixing of clast forms caused by glacial erosion must also be considered similar, both in tills and on moraine shores, before washing takes place. It is therefore justified to compare these two different kinds of samples with one another. Hence the error that may arise by comparing samples taken $25 \mathrm{~km}$ from each other (the extreme distance) is not significant. The field area in similar studies that resembles mine has also been large (DOBKINS and FOLK (1970) using the entire island of Tahiti-Nui, for example).

Dr. Seppälä's third major comment concerns longshore drift in the area. He claims that the original population of clasts was split up by longshore drift. I agree that we must be careful in drawing conclusions about sediment characteristics, and we should bear in mind how the different processes work in each individual case. In this study there is no longshore drift in the area or, if there is, its effects are insignificant. The sampling sites in most cases are located in small coves. According to my observations on painted pebbles and cobbles over a period of five years, none travelled past the small promontories marking the limits of the coves. On the contrary, they remained in their own small coves, travelling to and fro along the shore. The mean net distance travelled along the shore was only 0.3-0.4 $\mathrm{m}$ a year. We can therefore exclude the possibility that longshore drift has caused shape sorting in the area. Shape-sorting bias caused by waves and surf action at right angles to the shoreline was avoided by taking sample clasts in the whole of the area included between the breaker zone and the upper beach. The samples thus included the most discshaped clasts of the upper beach and the most rodshaped and most spherical clasts on the shore-foot (see MOSS, 1963; DOBKINS and FOLK, 1970). The shape changes observed in moraine-shore clasts must therefore mainly have been caused by abrasion taking place on the shore, not by longshore drift. Ice action in the area has also been found to be rather insignificant (PYÖKÄRI, 1978), and ice push does not cause shape sorting.

As to Dr. Seppälä's minor comments, I disagree that an increase in sphericity goes hand in hand with an 
increase in roundness; it is not so on the shore. As clasts are transported on the shore, their shape changes in most cases, becoming more oblate as roundness increases, i.e. abrasion causes them to flatten and become more disc-shaped. In my opinion, the oblate-prolate index is the best indicator of abrasion. As to $\mathrm{Dr}$. Seppälä's argument that waves have only sorted the clasts according to their form, size, and distance travelled and then accumulated them in certain parts on the shore, he has not pursued his thinking to its logical conclusion. Where are those clasts that have been only slightly rounded and whose axial ratios are largely unchanged? Such clasts can be found in till in all the studied size classes, but there are none on the shore except a few in the largest size class. The explanation is simple: they have been abraded.

Dr. Seppälä also asks why the till samples were not taken from the same places as the shore material by digging through the shore deposits to the original glacial till underneath. In the Airisto area, till strata are thin and it is almost impossible, unfortunately, to get unwashed till from present shores. The thickness of till layers ought to be about 2-3 $\mathrm{m}$ to avoid errors in sampling washed till. Furthermore, sampling of till from undershore material does not necessarily ensure that the material would be more comparable for the study than that obtained from farther afield, because we do not know with certainty where the shore clasts came from, as Dr. Seppälä himself admits. In addition, to find 20 trondhjemite clasts of $128-256 \mathrm{~mm}$ would require considerable excavation (about $75 \mathrm{~m}^{3}$ ) at each sampling site on the shore. This would require an excavator, special permits, and a lot of money. For these reasons trondhjemite till clasts were taken from building sites nearest the studied moraine shores. They were used because, statistically, they are very probably similar to the trondhjemite clasts before washing in the Airisto area, and at the same time the risk of sampling washed till was avoided.

Science often progresses in small steps. The conclusions of this study support more recent studies rather than older ones. Both abrasion and shape sorting may occur on shores but which plays a greater role depends on the locality. In the Airisto area, abrasion is more probable, because longshore drift has not been observed there and shape sorting perpendicular to the shore was avoided by the sampling technique. Of course the reading of an article which is not from the reader's own research field may cause difficulty and sometimes even lead to rather doubtful conclusions. I am sorry if my study has been difficult to understand.

\section{REFERENCES}

DOBKINS, J.E. and FOLK, R.L. (1970): Shape development on Tahiti-Nui, J. Sed. Petrol., Vol. 40, p. 1167-1203.

HÄRME, M. (1960): Explanation of the map of rocks, The general geological map of Finland, sheet B 1 Turku, 78 p.

HIETANEN, A. (1947): Archean geology of the Turku district in Southwestern Finland, Bull. Geol. Soc. Amer., Vol. 58, p. 1019-1084.

KAITANEN, V. and STRÖM, O. (1978): Shape development of sand-stone cobbles associated with the Säkylä-Mellilä esker, southwest Finland, Fennia, Vol. 155, p. 23-67.

PYÖKÄRI, M. (1978): Transportation of shore stones by ice in the Airisto area, SW Finland, winter 1975/76, Publ. Inst. Geogr. Univ. Turkuensis, Vol. 84, 18 p.

- (1980): Shape development of trondhjemite pebbles and cobbles on shores in the southwestern Finnish Archipelago, Géogr. phys. Quat., Vol. 34, p. 335-350. 